\title{
Impact of Integrated Technologies of Enhanced Oil Recovery on the Changes in the Composition of Heavy Oil
}

\author{
Yury V. Savinykh*, \\ Darya I. Chuykina and Larisa D. Stakhina \\ Institute of Petroleum Chemistry $S B R A S$ \\ Tomsk, Russian Federation
}

Received 15.11.2018, received in revised form 26.10.2019, accepted 17.01.2020

\begin{abstract}
This paper deals with the impact of an integrated technology for enhanced oil recovery on the composition of high-viscosity heavy oil produced at the Usinskoye oilfield (Russia, Komi Republic). In order to increase the effectiveness of the thermal-steam stimulation, a surfactant-based composition generating carbon dioxide and an alkaline buffer system is injected into the formation. The analysis of the oil composition is performed via the methods of gradient-displacement liquid adsorption, gas-liquid chromatography, and IR spectroscopy. The results obtained show that two parallel processes are proceeding when pumping an oil-displacing composition. The first process is the additional extraction of residual oil. This process is controlled by an increase in the content of resin-asphaltene substances in oil. The second process is an increase in the coverage of reservoir and the involvement into the development of previously uncovered areas with oil compositionally similar to that at the beginning of development. Using the results of the analysis of the component composition, the individual composition of alkanes, and structural fragments of oil samples in order to control the development of the Usinskoye oilfield, the frontal oil-water boundary advance of the Northern area in the direction of the upper production facility is determined. The obtained patterns of changes in the oil composition after the application of an integrated technology using a surfactant-based composition can be characteristic of other deposits of heavy oil occurring in low-permeability reservoirs.
\end{abstract}

Keywords: heavy oil, enhanced oil recovery, surfactants, group chemical composition, adsorption chromatography, gas-liquid chromatography, IR spectroscopy.

Citation: Savinykh Yu.V., Chuykina D.I., Stakhina L.D. Impact of integrated technologies of enhanced oil recovery on the changes in the composition of heavy oil, J. Sib. Fed. Univ. Chem., 2020, 13(1), 17-24. DOI: 10.17516/1998-2836-0162

(C) Siberian Federal University. All rights reserved

This work is licensed under a Creative Commons Attribution-NonCommercial 4.0 International License (CC BY-NC 4.0).

* Corresponding author E-mail address: yu-sav2007@yandex.ru 


\title{
Влияние комплексных технологий \\ интенсификации нефтеотдачи \\ на изменение состава тяжелой нефти
}

\author{
Ю.В. Савиных, Д.И. Чуйкина, Л.Д. Стахина \\ Институт химии нефти СО РАН \\ Российская Федерация, Томск
}

\begin{abstract}
Аннотация. В настоящей работе изучено влияние комплексной технологии для интенсификации нефтеотдачи на состав добытой тяжелой высоковязкой нефти на Усинском месторождении (Россия, Республика Коми). Для увеличения эффективности паротеплового воздействия производилась закачка композиции на основе поверхностно-активных веществ, генерирующая в пласте углекислый газ и щелочную буферную систему. Для анализа состава нефти были использованы методы градиентно-вытеснительной жидкостной адсорбционной и газожидкостной хроматографии, ИК-спектроскопии. Полученные результаты показали, что при закачке нефтевытесняющей композиции наблюдаются два параллельных процесса. Первый процесс - доотмыв остаточной нефти. Этот процесс контролируется увеличением содержания в нефти смолисто-асфальтеновых веществ. Второй процесс - увеличение охвата пласта и подключение в разработку ранее не задействованных участков с нефтью, сходной по составу с нефтью в начале разработки. Использование результатов анализа компонентного состава, индивидуального состава алканов, структурных фрагментов образцов нефти для контроля разработки Усинского месторождения позволило определить фронт продвижения контура нефтеносности Северного участка в направлении верхнего объекта. Полученные закономерности изменения состава нефти после воздействия комплексной технологии с применением композиции на основе поверхностно-активных веществ могут быть распространены и на другие месторождения тяжелой нефти, залегающей в низкопроницаемых коллекторах.
\end{abstract}

Ключевые слова: тяжелая нефть, повышение нефтеотдачи, поверхностно-активные вещества, групповой химический состав, адсорбционная хроматография, газожидкостная хроматография, ИК-спектроскопия.

Цитирование: Савиных, Ю.В. Влияние комплексных технологий интенсификации нефтеотдачи на изменение состава тяжелой нефти / Ю.В. Савиных, Д.И. Чуйкина, Л.Д. Стахина // Журн. Сиб. федер. ун-та. Химия, 2020. 13(1). С. 17-24. DOI: $10.17516 / 1998-2836-0162$

\section{Introduction}

Total World crude oil reserves are approximately 9-1 trillion barrels, where heavy oil and bitumen are more than $2 / 3$. Canada and Venezuela each possess approximately $2-3$ trillion barrels of eight trillion barrels of heavy oil and bitumen resources $[1,2]$. Russian reserves of heavy high-viscosity oil are estimated at $44-52$ billion barrels. The majority of deposits (71.4\%) are located in the Volga-Ural 
and West Siberian oil and gas regions. At the same time, $60.4 \%$ of the all-Russian reserves of heavy oils and $70.8 \%$ of viscous oils are accounted for the Volga and Ural regions. The deposits of heavy oil have been found in the republics of Tatarstan, Bashkortostan, Udmurtia, and in Samara and Perm regions [3]. The efficient development of heavy oil and bitumen resources has an important impact on global energy supply. Unlike light, low-viscosity oil, these types of crude oil are usually characterized by high viscosity and density under initial temperature conditions of the reservoir and require a special approach to their extraction [4]. Since viscous oil is temperature sensitive, it would be most rational to use thermal processes. The conventional thermal methods for developing oil fields (in their various modifications) are usually clustered into three groups: in-situ combustion, thermal steam treatment of bottom-hole zones of wells, and injection of steam or hot water as heat carriers into the reservoir (nonisothermal displacement) $[5,6]$.

The main methods of long-term and large-scale impact on the oil reservoir are hot water flooding or steam-stimulation. For this purpose, the hot fluid is continuously pumped into the reservoir. The formation rock and fluids around the wells heat up, the temperature rises, the viscosity of a heavy oil decreases, while its mobility increases. This method is the main one for the extraction of heavy oil and bitumen resources worldwide [7].

Flooding by gel-forming polymers has proven to be economically and technically successful in many oil recovery enhancement (EOR) projects, which can often increase oil recovery by $12-15 \%$ $[8,9]$.

The injection of an oil-displacing composition based on surfactants and an alkaline buffer system has proven itself to be good for increasing the oil recovery coefficient and increasing the duration of the effect of steam stimulation. In the course of oil displacement, surfactants affect the following interrelated factors: interfacial tension at the oil-water boundary and surface tension at the water-rock and oil-rock interfaces due to their adsorption at these interfaces. In addition, the effect of surfactants is manifested in the change in the selective wetting of the rock surface with water and oil, breakdown and washing off of the oil film from the rock surface, the stabilization of dispersion of oil in water, the increase in water flood displacement efficiency during stimulated displacement and capillary imbibitions, and in the increase in relative phase permeability of porous media [10, 11].

The use of various EOR-technologies leads not only to an increase in the oil recovery coefficient, but also to a change in the composition of produced oil $[12,13]$. In this regard, an indepth study of the effect of EOR on the composition of produced fluids in water-flooded reservoirs is relevant. In order to identify the patterns in changes of the composition of oil produced after the use of integrated EOR-technologies, the oil samples from the Usinskoye oilfield were taken and investigated.

\section{Experimental}

Oil samples. The heavy crude oil (8 samples) was sampled from the Usinskoye oil field (Komi Republic, Russia) before and after the treatment with a NINKA system (EOR).

EOR compositions. The oil-displacing NINKA composition based on alkaline buffer system, carbamide, and surfactant was developed at the Institute of Petroleum Chemistry of the SB RAS [14].

SARA analysis. The oil samples were analyzed for the content of the main SARA components (saturated and aromatic hydrocarbons, resins, and asphaltenes). 
The analysis of the group composition of oil was carried out by the method of gradient displacement liquid adsorption chromatography on silica gel. The samples were analyzed for the content of saturated (paraffin-naphthenic) hydrocarbons (SHCs), polycyclo-aromatic hydrocarbons (PAHCs), neutral resins (NR), sour resins (SR), and asphaltenes (AS). Oil separation was carried out using a 'Gradient' instrument manufactured by Bash NIINP [15]. The withdrawal of the oil fraction containing a mixture of saturated and aromatic hydrocarbons was carried out by the method of liquid adsorption chromatography (LAC). Crude oil in an amount of $0.1 \mathrm{~g}$ was applied on aluminum oxide of IV degree activity and then the chromatographic fraction was eluted with $100 \mathrm{ml}$ of hexane. The chromatographic fraction was evaporated to a volume of $1 \mathrm{ml}$ using a vacuum rotary evaporator. The concentrate obtained was analysed using a Chromos GC-1000 gas chromatographer equipped with a $25 \mathrm{~m}$ long capillary column with an OV-101 phase. Operating mode was as follows: helium was used as a carrier gas and the temperature of evaporator and interface was $250^{\circ} \mathrm{C}$. The column was heated in the linear mode of temperature programming. The initial temperature $\mathrm{T}_{\text {init }}=80^{\circ} \mathrm{C}$ was increased at a rate $10 \mathrm{deg} / \mathrm{min}$ up to maximum temperature $\mathrm{T}_{\max }=280^{\circ} \mathrm{C}$.

IR spectroscopy. The IR spectra were recorded in a thin layer in the range $400-4000 \mathrm{~cm}^{-1}$ using a Thermo Scientific 'Nikolet 5700' FTIR Spectrometer equipped with a Raman module (Thermo Electron Corporation, USA). The spectroscopic coefficient, C, is the ratio of the optical densities (D) of the characteristic absorption bands in the IR spectral region, which correspond to the respective types of bonds.

To determine the change in the content of certain groups and bonds in the samples, the optical density ratios were used [16]:

$\mathrm{C}_{1}=\mathrm{D}_{1380+720} / \mathrm{D}_{1610}$ - the conventional ratio of aliphatic structures to aromatic structures;

$\mathrm{C}_{2}=\mathrm{D}_{960} / \mathrm{D}_{1465}$ - the conventional ratio of naphthenic structures to aliphatic structures;

$\mathrm{C}_{3}=\mathrm{D}_{1610} / \mathrm{D}_{720}$ - the conventional ratio of aromatic structures to paraffinic structures;

$\mathrm{C}_{4}=\mathrm{D}_{1380} / \mathrm{D}_{1465}$ - the branching coefficient which characterizes the conventional content of $\mathrm{CH}_{3}$ - groups;

$\mathrm{C}_{5}=\mathrm{D}_{1710} / \mathrm{D}_{1465}-$ the conventional content of $\mathrm{C}=\mathrm{O}$ groups of carboxylic acids.

\section{Results and discussion}

Experience in the development of domestic and foreign oilfields using steam stimulation shows that the effective implementation of the technology of cyclic steam well treatment requires a careful consideration of the geological and physical characteristics of the reservoir and a study of scientific background of the process parameters.

The Usinskoye oilfield is located in the Usinsk district of the Komi Republic, $115 \mathrm{~km}$ north of the city of Pechora [17]. Structurally, the Usinsk uplift over all horizons of the sedimentary cover represents an asymmetric anticlinal fold, which strikes the north-west of north. The Permocarbon deposit of the Usinsk oilfield is a single hydrodynamic system. The three following productive formations or production facilities are distinguished in the cross-section of the deposit: I - lower production facility (LPF), II - middle (MPF) and III - upper (UPF). The undersaturated oil in the reservoir is characterized by a high viscosity of 586-2024 $\mathrm{mPa}^{*} \mathrm{~s}$ and a high density of up to $960 \mathrm{~kg} / \mathrm{m}^{3}$. Currently, the Usinskoye oilfield is at the fourth stage of development, which is accompanied by high water cut and low oil production rates. 
Investigation of the oils sampled from various production facilities of the Usinskoye oilfield: lower (LPF), middle (MPF) and upper (UPF) revealed features and significant differences in their composition [18]. The main differences are observed in the content of paraffinic, naphthenic, and aromatic hydrocarbons. These data were used to differentiate oil-bearing facilities and to monitor the development of the Usinskoye field after application of the methods of enhanced oil recovery.

In 2017, in the Northern area of the Usinskoye oilfield, a cyclic steam treatment of the formation (CST) was performed, followed by the injection of the NINKA oil-displacing composition. The introduction of oil-displacing composition into the reservoir was carried out through production wells, which provided a significant increase in oil production.

The results of the changes in composition of the oil samples taken from the Northern area of the Usinskoye oilfield after application of the integrated production technology are shown in Table 1.

The area under consideration is located in the attic zone of the reservoir, where all three facilities (upper, middle and lower) were penetrated, which explains the differences in the composition of the oil produced. A comparison of the group composition of oil samples extracted after application of the integrated method in 2018 with earlier samples (2017) taken from the same wells has showed a difference in the composition of oils. After injection of the composition the content of paraffin-naphthenic (saturated) hydrocarbons (SHCs) in the oil samples increased by $7-15 \%$. Paraffin-naphthenic hydrocarbons were represented by alkanes and saturated cyclic structures. The total content of aromatic and polycycloaromatic hydrocarbons (PAHCs) has insignificantly changed. The main amount of resins (7-23\%) are sour (SR), while the content of neutral resins (NR) does not exceed 5\% rel. After injection of the NINKA composition, a decrease in the content of resin-asphaltene substances (RAS) by 2-14\% was observed. The RAS is the total content of neutral and sour resins and asphaltenes (As) (Table 1). Gas chromatography was used to analyze the hexane fractions (saturated hydrocarbons) of oil separated by LAC (Fig. 1).

The data obtained for the group composition of the oils indicate that after the composition was injected into the wells, the zones of the reservoir previously water unflushed were included into the

Table 1. Group composition of the oil samples taken from the Northern area of the Usinskoye oilfield

\begin{tabular}{|c|c|c|c|c|c|c|c|}
\hline \multirow{2}{*}{ Well No. } & \multirow{2}{*}{$\begin{array}{c}\text { Date of } \\
\text { sampling }\end{array}$} & \multicolumn{7}{|c|}{ Content, wt\% } \\
\cline { 3 - 8 } & SHCs & PAHCs & NR & SR & As & RAS \\
\hline 81 XX & 12.2017 & 60 & 16 & 3 & 7 & 14 & 24 \\
81 XX & 04.2018 & 67 & 12 & 2 & 8 & 10 & 20 \\
$60 X X$ & 04.2017 & 43 & 19 & 4 & 23 & 11 & 38 \\
$60 X X$ & 04.2018 & 58 & 18 & 2 & 13 & 9 & 24 \\
XX62 & 12.2017 & 50 & 23 & 5 & 17 & 5 & 27 \\
XX62 & 04.2018 & 57 & 18 & 2 & 13 & 10 & 25 \\
XX68 & 04.2017 & 52 & 13 & 2 & 15 & 17 & 34 \\
XX68 & 04.2018 & 66 & 9 & 1 & 13 & 11 & 25 \\
\hline
\end{tabular}



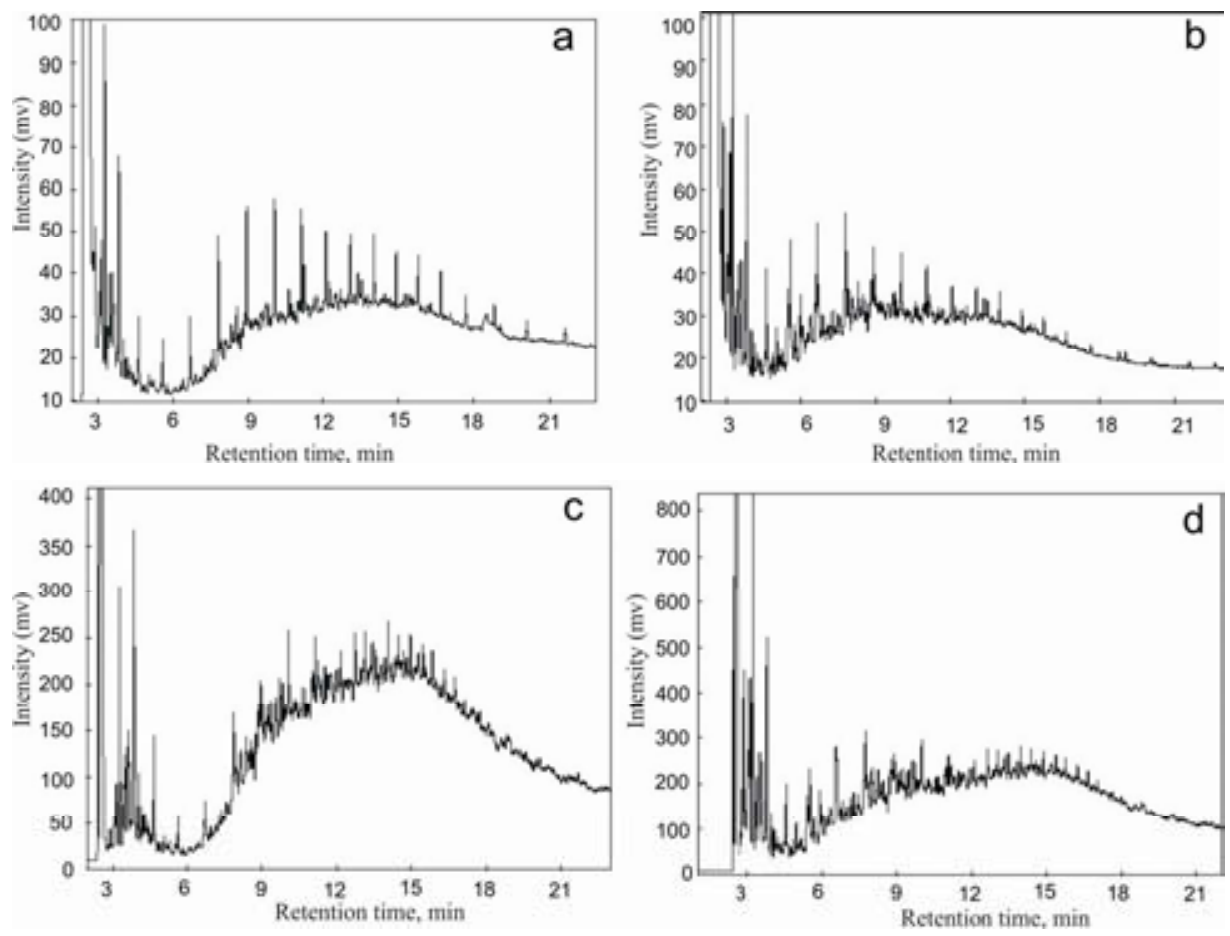

Fig. 1. Chromatograms of saturated hydrocarbon fraction of oil samples from the Northern area of the Usinskoye oilfield: a - well No. 60XX (12.2017); b - well No. 60XX (04.2018); c - well No. 81XX (11.2017); d - well No. $81 X X(04.2018)$

development. These reservoir zones contained the oil similar in its composition to the initial one produced without EOR application. These data make it possible to appreciate the contributions of residual oil and that of bypassed oil from the not water-flooded pillars to the well production. The most noticeable differences in the molecular mass distribution (MMD) of n-alkanes are observed for oil samples from wells No. 60XX and No. 81XX. These differences in the composition are due to the fact that different operational facilities objects are under development. The oil of the lower production facility (well No. $81 \mathrm{XX}$ ) is characterized by the almost complete absence of n-alkanes and the presence of a high 'naphthenic' hump (Fig. $1 \mathrm{c}$ ), while the oils from the upper and middle production facilities (well No. 60XX) contain high concentrations of paraffinic hydrocarbons (Fig. $1 \mathrm{a}$ ) [18]. The chromatograms of hexane fractions isolated from the initial oil samples showed that crude oil from the well No. 60XX was also produced predominantly from the upper and middle facilities, while the crude oil from the well No. $81 \mathrm{XX}$ was extracted from the lower facility. Figure 1 shows no significant changes in the MMD of $n$-alkanes for the same well after injection of the composition (Fig. $1 \mathrm{a}, \mathrm{b}, \mathrm{c}, \mathrm{d}$ ). This indicates that the production facility for each well has not changed after injection of the composition.

To characterize the oils, the spectral coefficients $C_{1}-C_{5}$ were calculated from the data of IR spectrometry (Table 2).

Based on the data, it was found that all samples belong to the naphthenic-aromatic type of oils $\left(C_{3}=1.43-1.55\right)$. A low degree of aliphaticity $\left(C_{1}=3.14-3.51\right)$ suggests a low content of alkane structures. Small differences were established for the $\mathrm{C}_{1}$ coefficient characterizing the content of paraffin 
Table 2. Spectral coefficients of oil samples from the Northern area of the Usinskoye oilfield

\begin{tabular}{|c|c|c|c|c|c|c|}
\hline \multirow{2}{*}{ Well No. } & \multirow{2}{*}{$\begin{array}{c}\text { Date of } \\
\text { sampling }\end{array}$} & $\mathrm{C}_{1}$ & $\mathrm{C}_{2}$ & $\mathrm{C}_{3}$ & $\mathrm{C}_{4}$ & $\mathrm{C}_{5}$ \\
\cline { 3 - 7 } & 12.2017 & 3.34 & 0.07 & 1.55 & 0.57 & 0.06 \\
$81 \mathrm{XX}$ & 04.2018 & 3.30 & 0.08 & 1.54 & 0.58 & 0.06 \\
$60 \mathrm{XX}$ & 04.2017 & 3.31 & 0.09 & 1.43 & 0.60 & 0.07 \\
$60 \mathrm{XX}$ & 04.2018 & 3.51 & 0.07 & 1.54 & 0.58 & 0.06 \\
$\mathrm{XX62}$ & 12.2017 & 3.27 & 0.08 & 1.53 & 0.59 & 0.07 \\
XX62 & 04.2018 & 3.44 & 0.07 & 1.55 & 0.58 & 0.06 \\
$\mathrm{XX68}$ & 04.2017 & 3.39 & 0.08 & 1.49 & 0.58 & 0.06 \\
XX68 & 04.2018 & 3.14 & 0.09 & 1.45 & 0.60 & 0.07 \\
\hline $\mathrm{C}_{1}=\mathrm{D}_{1380+720} / \mathrm{D}_{1610} ; \mathrm{C}_{2}=\mathrm{D}_{975} / \mathrm{D}_{1465} ; \mathrm{C}_{3}=\mathrm{D}_{1610} / \mathrm{D}_{720} ; \mathrm{C}_{4}=\mathrm{D}_{1380} / \mathrm{D}_{1465} \mathrm{C}_{5}=\mathrm{D}_{1710} / \mathrm{D}_{1465}$ \\
\hline
\end{tabular}

structures, which is due to the oil extraction from different production facilities. This is confirmed by data obtained by gradient displacement chromatographic analysis.

The optical densities D of the band in the region of $1710 \mathrm{~cm}^{-1}$ are in the range $0.04-0.06$, which is typical for the presence of aliphatic oxygen-containing NINKA compounds. Coefficient $\mathrm{C}_{5}$ is 0.6-0.7, which suggests the oxidized type of oil samples. The results of IR spectrometry showed that no significant changes were observed in the ratio of naphthenic, aromatic, and oxygen-containing fragments and structures for both initial oil samples and those taken after application of the integrated EOR-technology.

\section{Conclusions}

Based on the study of the dynamics of changes in the composition of oil produced after the application of integrated EOR-technologies, the effectiveness of methods of oil recovery enhancement has been shown. The use of the NINKA composition in conjunction with the PCO in the Northern area of the Usinskoye oilfield has showed that new low-permeability interlayers were involved in the development when using the integrated EOR-technology. This is due to a number of processes, including counterflow capillary percolation and a decrease in surface tension at the rock-oil boundary under the influence of the NINKA composition containing a surfactant and an alkaline buffer system.

\section{Acknowledgements}

The work was performed within the framework of the Program of Fundamental Scientific Research of the State Academies of Sciences (Project V.46.2.3 No. 0370-2019-0002).

\section{References}

1. Dusseault M.B. Comparing Venezuelan and Canadian heavy oil and tar sands. Paper 2001-061 presented at the Petroleum Society's Canadian International Petroleum Conference. Calgary, Alberta, Canada, June 12-14; 2001.

2. Meyer R.F., Attanasi E.D., Freeman P.A. Heavy oil and natural bitumen resources in geological basins of the world. Open File-Report 2007-1084, U.S. Geological Survey; 36 p. 
3. Makarevich V.N., Iskritskaya N.I., Bogoslovsky S.A. Resource potential of heavy oil deposits in the European part of the Russian Federation. Petroleum Geology. Theoretical and Applied Studies. 2012. Vol. 7(3), P. 1-16. (In Russ.)

4. Iskritskaya N.I., Makarevich V.N., Shchepochkina A.A. Main trends in the development of hard-to-extract oil reserves of the Russian Federation. Oil and gas geology 2015. No. 4, P. 62-66. (In Russ.)

5. Antoniadi D.G. Scientific foundationsis for the development of oil deposits by thermal methods. Moscow: Nedra, 1995. 314 p. (In Russ.)

6. Wu Z., Liu H. Investigation of hot-water flooding after steam injection to improve oil recovery in thin heavy-oil reservoir. Journal of Petroleum Exploration and Production Technology 2019. Vol. 9(2), P. $1547-1554$.

7. Burkova A.A. Cyclic steam treatment of the bottom-hole formation zone. Bulatov Scientific Conference 2018. Vol. 2-1, P. 98-104. (In Russ.)

8. Wei B., Romero-Zerón L., Rodrigue D. Oil displacement mechanisms of viscoelastic polymers in enhanced oil recovery (EOR): a review. Journal of Petroleum Exploration and Production Technology 2014. Vol. 4(2), P. 113-121.

9. Wei B., Laiming Lu, et al. From Phase Behavior to Understand the Dominant Mechanism of Alkali-Surfactant-Polymer Flooding in Enhancement of Heavy Oil Recovery. Journal of Surfactants and Detergents 2017. Vol. 20(2), P. 355-366.

10. Sreela Pal, M. Mushtaq et al. Review of surfactant-assisted chemical enhanced oil recovery for carbonate reservoirs: challenges and future perspectives. Petroleum Science 2018. Vol. 15(1), P. 77-102.

11. Fusheng Zhang, Jian Ouyang et. all. Enhanced oil recovery from heavy oil reservoirs utilizing a displacement agent. Chemistry and Technology of Fuels and Oils 2012. Vol. 48(3), P. 202-207. (In Russ.)

12. Savinykh Yu.V., Chuykina D.I. Change in the composition of high viscosity oil upon contact with surfactants. Oil \& Gas Journal Russia 2017. No. 3, P. 84-87. (In Russ.)

13. Chuikina D., Russkikh I.V., Stakhina L.D., Serebrennikova O.V. Investigation of the Composition of High-Viscosity and Heavy Oils in the Course of EOR-Process Simulation. Journal of Siberian Federal University. Chemistry 2017. Vol. 2(10), P. 206-215. (In Russ.)

14. Altunina L.K., Kuvshinov V.A., Kuvshinov I.V. Surfactant systems for effective thermalsteam reservoir stimulation. Oil \&Gas Journal Russia 2010. No. 6, P. 68-75. (In Russ.)

15. Sokolova V.I., Kolbin M.A. Liquid chromatography of petroleum products. Moscow: Chemistry, 1984. P. 41-51. (In Russ.)

16. Pentin Yu.A., Vilkov L.V. Physical Methods in Chemistry. Moscow: Mir Publishing House, 2003, 683 p. (In Russ.)

17. Chuykina D.I., Serebrennikova O.V., Stakhina L.D., Altunina L.K. Features of the geological structure of the Usinskoye deposit and composition of extracted oil. Exposition Oil \& Gas 2018. No. 1, P. 18-21 (electronic journal http://runeft.ru/archive/2017/1_2018.htm). (In Russ.)

18. Chuikina D.I., Kozlov V.V., Stakhina L.D., Savinykh Y.V. Study of the Composition of Heavy Oil during the Simulation of Oil Displacement in Porous Media. Journal of Siberian Federal University. Chemistry 2018. Vol. 3(11), P. 323-332. (In Russ.) 